\title{
Analysis of virtual water flows associated with the trade of maize in the SADC region: importance of scale
}

\author{
J. M. Dabrowski, E. Masekoameng, and P. J. Ashton \\ CSIR, Natural Resources and Environment, P.O. Box 395, Pretoria, 0001, South Africa \\ Received: 18 July 2008 - Published in Hydrol. Earth Syst. Sci. Discuss.: 12 September 2008 \\ Revised: 14 August 2009 - Accepted: 25 September 2009 - Published: 23 October 2009
}

\begin{abstract}
The concept of virtual water encourages a country to view agricultural crops in terms of the amount of water required to produce those crops, with a view to implementing trading policies that promote the saving of scarce water resources. Recently, increased attention has focussed on partitioning the virtual water content of crops into green and blue water (derived from rainfall and irrigation, respectively) as the latter has higher opportunity costs associated with its use and therefore impacts directly on scarcity. Maize is the most important crop traded within the SADC region. South Africa is the largest producer and exporter of maize, with the majority of its exports destined for other SADC countries. In comparison to other SADC countries, South Africa produces maize relatively efficiently, with a low virtual water content and a high green $\left(868 \mathrm{~m}^{3} \mathrm{t}^{-1}\right)$ to blue $\left(117 \mathrm{~m}^{3} \mathrm{t}^{-1}\right)$ water ratio. The blue water content is however higher than for maize produced in all other SADC countries, with the exception of Namibia $\left(211 \mathrm{~m}^{3} \mathrm{t}^{-1}\right)$. Current trade patterns therefore result in a net expenditure of blue water $\left(66 \times 10^{6} \mathrm{~m}^{3}\right)$, almost all of which is exported by South Africa $\left(65 \times 10^{6} \mathrm{~m}^{3}\right)$. South Africa is one of the most water scarce countries in the region and analysis of virtual water flows indicates that current SADC maize trading patterns are influenced by national productivity as opposed to water scarcity. The virtual water content of maize was estimated for each of South Africa's nineteen Water Management Area's (WMA) and used as a proxy to represent water use efficiency for maize production. The virtual water content varied widely across all of the WMAs, ranging from $360 \mathrm{~m}^{3} \mathrm{t}^{-1}$ in the Ustutu Mhlatuze to $1000 \mathrm{~m}^{3} \mathrm{t}^{-1}$ in the Limpopo. A comparison of the virtual water content and production of maize (expressed as a percentage of the total national production) identified those WMAs where maize production is highly water inefficient
\end{abstract}

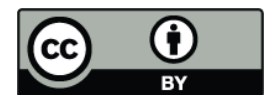

Correspondence to: J. M. Dabrowski (jdabrowski@csir.co.za) (e.g. Lower Orange and Limpopo WMAs). Results suggest that, while a national estimate of the virtual water content of a crop may indicate a relatively efficient use of water, an analysis of the virtual water content at smaller scales can reveal inefficient use of water for the same crop. Therefore, analysis of the virtual water content of crops and trading of agricultural products at different spatial scales (i.e. regional, national and WMA) could be an important consideration within the context of water allocation, water use efficiency and alleviation of water scarcity.

\section{Introduction}

South Africa is a water scarce country and water resources available in many of its 19 Water Management Areas (WMAs) have already been over allocated (DWAF, 2004), with irrigated agriculture accounting for approximately $60 \%$ of national water use (FAO, 2005). Within the Southern African Development Community (SADC), maize is the most important staple food source and South Africa is the largest producer (producing 11749000 tonnes on a total area of 3233000 ha; DoA, 2007) and exporter of maize in the region (Maasdorp, 1998). Production of one metric tonne of maize in South Africa requires approximately $1609 \mathrm{~m}^{3}$ of water (Chapagain and Hoekstra, 2004); approximately $9 \%$ of South Africa's maize is irrigated while the balance is rain-fed (FAO, 2005). Given the water requirements of maize and the large quantities produced each year, current production and trade trends in SADC are likely placing increased pressure on South Africa's scarce water resources.

Virtual water is the water required for production of commodities (Yang and Zehnder, 2007). The concept of virtual water trading advocates the idea that water-scarce countries should increasingly meet their food requirements by importing crops from water-rich countries (Horlemann and Neubert, 2007), thereby saving the amount of water that

Published by Copernicus Publications on behalf of the European Geosciences Union. 
would have been required to produce the crop locally (WWC, 2004). The most positive effect generated by virtual water trade is the water savings that that are generated in the countries that import agricultural products (Chapagain et al., 2006). South Africa has gradually shifted from being self sufficient in terms of crop production and has reduced the production of low value crops such as maize, wheat and other cereals, while increasing production of higher value crops, such as citrus (Earle, 2001). This has a positive impact by generating more monetary value per unit of water used. Given that maize is the most important agricultural crop traded in the SADC region, there are likely to be large volumes of virtual water associated with maize trade. Analysis of virtual water flows in the region is relevant in that the SADC region is characterized by four countries (Botswana, Namibia, South Africa and Zimbabwe) that are regarded as severely water deficient (Falkenmark, 1989; WRI, 2008) and which could therefore benefit from the implementation of a virtual water trading policy.

The first objective of this paper was therefore to analyse virtual water flows associated with maize trade at the regional level (i.e. within SADC) with a particular focus on the impact on water resources in South Africa. Secondly, the virtual water content of maize is calculated for each of South Africa's 19 WMAs so as to determine the relative water-use efficiency for maize in each of the WMAs. This was done as South Africa experiences highly heterogeneous rainfall, ranging from less than $100 \mathrm{~mm}$ per year in the west to about $1200 \mathrm{~mm}$ per year in the east, with an annual average of approximately $495 \mathrm{~mm}$ (FAO, 2005). Only 35 percent of the country has a precipitation of $500 \mathrm{~mm}$ or more, while 44 percent has a precipitation of $200-500 \mathrm{~mm}$ and 21 percent has a precipitation of less than $200 \mathrm{~mm}$. For many WMAs in South Africa, the current demand for water exceeds supply, with agriculture being the largest user of water resources (DWAF, 2004). Clearly, in the case of these WMAs, an analysis of the virtual water content of crops at the WMA scale may provide valuable inputs into decision making with regards to sustainable allocation of limited resources. Within each objective, particular attention is paid to the partitioning of green (derived from rainfall) and blue (derived from irrigation) water and their respective impacts on regional (SADC) water savings and production efficiencies at the WMA level.

\section{Methodology}

\subsection{Importance of maize in the SADC region}

Our analysis included all of the countries comprising the Southern African development Community (SADC; Angola, Botswana, Democratic Republic of Congo, Lesotho, Madagascar, Malawi, Mauritius, Mozambique, Namibia, South Africa, Swaziland, Tanzania, Zambia and Zimbabwe). For each country a detailed trade matrix (for the year 2003) for export and import of maize was constructed using FAOSTAT data (FAO, 2007). The matrix provided information on the quantity of maize that was exported from and/or imported into a country (including the specific countries which maize is exported to and imported from). Using these matrices it was possible to calculate, for each SADC country, the percentage of maize trade (import and export) confined to other SADC countries only, and that confined to countries from the rest of the world. These matrices were combined to construct a single matrix showing only the quantity of maize imported into and exported out of other SADC members, for each country included in the analysis.

\subsection{Virtual water flows associated with maize in the SADC region}

\subsubsection{Virtual water calculations}

The blue, green and total virtual water content of maize was calculated for each SADC country, based on data collected for important maize growing areas in each country (Hartkamp et al., 2000). For each country, an average crop water and irrigation requirement was calculated using the FAO CROPWAT model (FAO, 2003). Effective rainfall was estimated to be the difference between the crop water and irrigation requirement. The blue virtual water content (BVW) was calculated as follows:

$\mathrm{BVW}=\frac{10 \times \mathrm{CIR} \times \mathrm{CA}_{\text {irr }}}{\mathrm{CP}_{\text {total }}}$

where CIR is the crop irrigation requirement $(\mathrm{mm}), \mathrm{CA}_{\mathrm{irr}}$ is the area (ha) of crop under irrigation and $\mathrm{CP}_{\text {total }}$ is the total amount of maize (tonnes) produced. Estimates of the area of maize under irrigation for each SADC country were obtained from the FAO Aquastat survey (FAO, 2005). Green virtual water content $(\mathrm{GVW})$ was calculated as follows:

$\mathrm{GVW}=\frac{10 \times(\mathrm{CWR}-\mathrm{CIR}) \times \mathrm{CA}_{\text {total }}}{\mathrm{CP}_{\text {total }}}$

where CWR is the crop water requirement $(\mathrm{mm})$ and $\mathrm{CA}_{\text {total }}$ is the total area under maize (ha). The total virtual water content is equal to the sum of the green and blue virtual water content for maize in the country. Using the trade matrix, the volumes of total virtual water exported and imported in maize trade was calculated for each SADC country. Virtual water export $\left(\mathrm{VW}_{\mathrm{ex}}\right)$ is the amount of water associated with exported maize, representing a water flow out of the producing country, and was calculated as follows:

$\mathrm{VW}_{\mathrm{ex}}=\mathrm{Q}_{\mathrm{ex}} \times \mathrm{VW}$

where $\mathrm{Q}_{\mathrm{ex}}$ is the quantity (in metric tonnes) of exported maize and VW is the total virtual water content $\left(\mathrm{m}^{3} \mathrm{t}^{-1}\right)$ of the crop, in the country which it is produced. Virtual water import $\left(\mathrm{VW}_{\mathrm{im}}\right)$ is the amount of water that virtually flows into the country in imported maize, and is equivalent to the 
amount of water that would have been required to produce maize in the importing country in question. $\mathrm{VW}_{\mathrm{im}}$ was determined according to the following equation:

$\mathrm{VW}_{\mathrm{im}}=\mathrm{Q}_{\mathrm{im}} \times \mathrm{VW}$

where $\mathrm{Q}_{\mathrm{im}}$ is the quantity (in metric tonnes) of the imported maize and VW is the total virtual water content maize in the importing country. For each exporting country, an overall saving was calculated by summing the net water savings associated with maize export to each of the corresponding importing countries. This figure gives an indication of the water savings associated with the export of maize from a particular country to other SADC nations. Similarly, for each importing country, an overall saving was calculated by summing the net water savings associated with maize imports from each of the corresponding exporting countries. The total water saving in the SADC region was calculated by summing the net savings for each exporting country. A trade matrix was constructed to detail the net virtual water flows associated with maize trade between countries.

\subsubsection{Blue water flows associated with maize in the SADC region}

The use of irrigation water (blue water) for agriculture constitutes a high opportunity cost, because it can be used by many alternative users (i.e. industry, domestic use, and maintenance of the integrity of aquatic ecosystems). In contrast, the use of rainfall by dryland agriculture (green water use) represents a beneficial use of water as there are comparatively fewer competing users. Therefore, an analysis of the virtual water trade in terms of blue water may give a more accurate representation of real water savings that accrue to a particular country. Accordingly an identical trade matrix was drawn up, as described above, to detail flows of blue water. The virtual blue water savings were calculated according to the following equation:

$\mathrm{NetVW}_{\text {Blue }}=\mathrm{Q} \times\left(\mathrm{BVW}_{\mathrm{ex}}-\mathrm{BVW}_{\mathrm{im}}\right)$

where $\mathrm{Q}$ is the quantity (in metric tonnes) of maize traded, $\mathrm{BVW}_{\mathrm{ex}}$ is the blue virtual blue water content of maize produced in the exporting country, and $\mathrm{BVW}_{\mathrm{im}}$ is the virtual blue water content of irrigated maize in the importing country.

\subsection{Impact of maize production at WMA scale}

Data on the area, production and proportion of irrigated and dryland maize in each of South Africa's WMAs were obtained from Statistics South Africa (STATSSA, 2002). Major maize production areas were identified for each WMA (Fig. 1) and crop water and irrigation requirements and effective rainfall were determined for each of these areas using the SAPWAT (Crosby and Crosby, 1999) computer software programme. SAPWAT is a programme designed to estimate crop irrigation requirements for the planning of water requirements for Water User Associations in South Africa. The programme is designed as a planning and management aid and relies on an extensive South African crop and climate database and contains data from over 350 weather stations located throughout the country. In order for the programme to calculate water requirements for a particular crop, it is necessary for the user to provide input in the form of a) selecting a weather station that is representative of the area in which the crop is grown; and b) crop information (crop type, month of planting). Collected data were used to calculate blue, green and total virtual water content for maize in each of the WMAs using Eqs. (1) and (2). The SAPWAT weather stations used for the derivation of water requirements are indicated on Fig. 1.

\section{Results}

\subsection{Trade analysis of maize}

In 2003, countries within the SADC region collectively exported 1018507 tonnes of maize, of which 79\% was exported to other SADC countries. South Africa is the largest exporter of maize in the SADC region, accounting for $75 \%$ of the total maize exports, of which $80 \%$ is destined for other SADC countries (Table 1), and, together with Tanzania accounts for $90 \%$ of the total quantity of maize exported from all SADC countries. Zimbabwe and Zambia are the largest importers of maize (accounting for almost $60 \%$ of the total), almost all of which originates from other SADC countries (Table 1). Most SADC countries import maize from other SADC countries. The exceptions are Mauritius, Tanzania and South Africa which, together, account for less than $10 \%$ of imported maize, the majority of which originates from countries outside of the SADC region.

\subsection{Virtual water content}

The average water requirements for maize grown in important maize production areas in each of the SADC countries vary from $413 \mathrm{~mm}$ in the DRC to $620 \mathrm{~mm}$ in Namibia (Table 2). Irrigation requirements are relatively low in most SADC countries, particularly for countries such as Angola, DRC, Malawi, Mauritius and Zambia, which receive high annual rainfalls. In contrast, countries with lower effective rainfalls such as Zimbabwe, South Africa, Namibia, Lesotho and Botswana, have comparatively high irrigation requirements for maize. Maize yields vary from 0.2 (Botswana) to as high as 6.6 (Mauritius) tha ${ }^{-1}$. South Africa, with an average of $2.7 \mathrm{tha}^{-1}$ produces higher yields than all SADC countries (with the exception of Mauritius). The virtual water content for maize across all SADC countries varies widely, from $748 \mathrm{~m}^{3} \mathrm{t}^{-1}$ in Mauritius to as much as $12402 \mathrm{~m}^{3} \mathrm{t}^{-1}$ in Botswana (Table 3). With the exception of Mauritius, South African maize has the lowest virtual water content, despite the fact that maize produced in South Africa has 

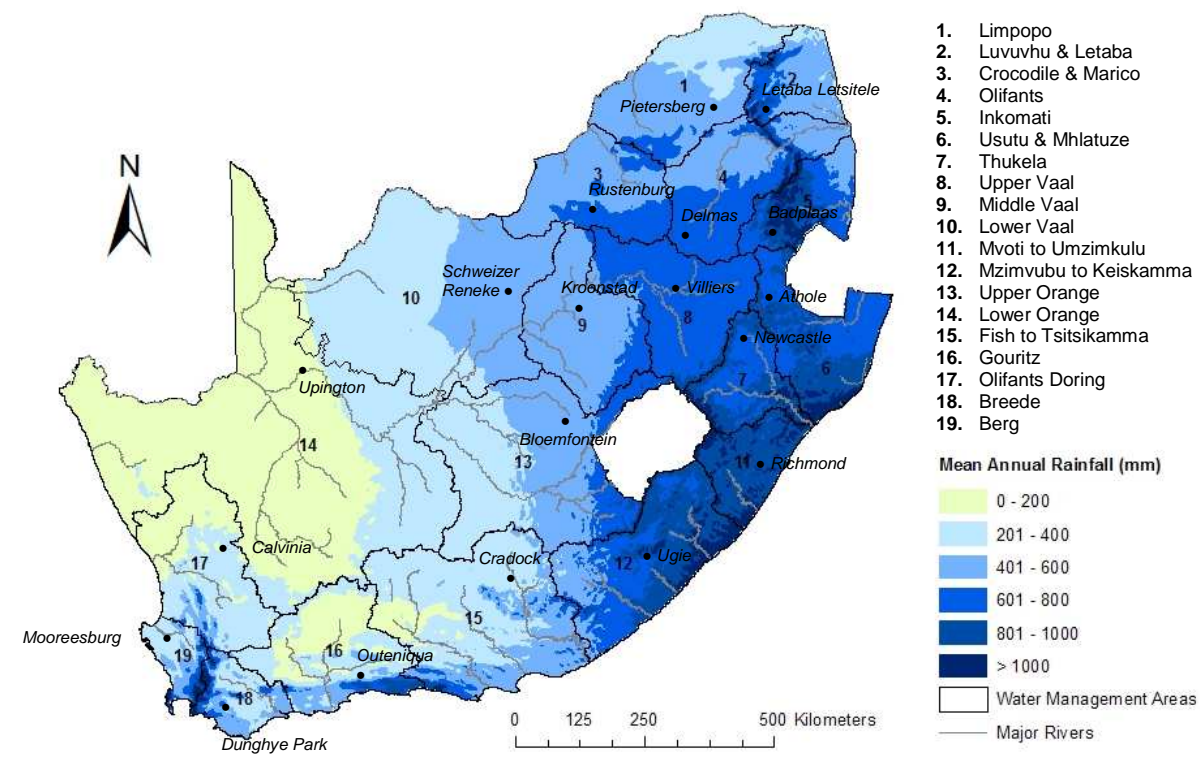

Fig. 1. Map showing South African Water Management Areas (WMAs), SAPWAT weather stations used to derive water requirements for maize in each of the WMAs and mean annual rainfall across the country.

Table 1. Quantity of maize exported out of and imported into each of the SADC countries (expressed as tonnes and as a percentage of the total).

\begin{tabular}{lrrrrrrrr}
\hline & \multicolumn{3}{c}{ Export } & & \multicolumn{3}{c}{ Import } \\
& \multicolumn{2}{c}{ Quantity } & \multicolumn{2}{c}{ Destination $(\%)$} & Quantity & \multicolumn{2}{c}{ Origin (\%) } \\
\hline Tonnes & $(\%)$ & SADC & Other & Tonnes & $(\%)$ & SADC & Other \\
\hline Botswana & 0 & $(0.0)$ & - & - & 26486 & $(2.3)$ & 100 & 0 \\
DRC & 986 & $(0.1)$ & 88 & 12 & 60369 & $(5.2)$ & 100 & 0 \\
Lesotho & 113 & $(<0.1)$ & 100 & 0 & 6951 & $(0.6)$ & 100 & 0 \\
Madagascar & 0 & $(0.0)$ & - & - & 150 & $(<0.1)$ & 100 & 0 \\
Malawi & 0 & $(0.0)$ & - & - & 6316 & $(0.5)$ & 63 & 37 \\
Mauritius & 54604 & $(5.0)$ & 36 & 64 & 54436 & $(4.7)$ & 59 & 41 \\
Mozambique & 18776 & $(1.7)$ & 100 & 0 & 80471 & $(7.0)$ & 100 & 0 \\
Namibia & 8899 & $(0.8)$ & 100 & 0 & 42103 & $(3.6)$ & 100 & 0 \\
South Africa & 815013 & $(75.1)$ & 80 & 20 & 13386 & $(1.2)$ & 0 & 100 \\
Swaziland & 640 & $(0.1)$ & 100 & 0 & 354 & $(<0.1)$ & 100 & 0 \\
Tanzania & 156193 & $(14.4)$ & 71 & 29 & 77990 & $(6.8)$ & 38 & 62 \\
Zambia & 28080 & $(2.6)$ & 100 & 0 & 191043 & $(16.5)$ & 95 & 5 \\
Zimbabwe & 1382 & $(0.1)$ & 100 & 0 & 521687 & $(45.2)$ & 100 & 0 \\
\hline
\end{tabular}

comparatively higher crop water requirements than other SADC countries. Of all the SADC countries, irrigation of maize only takes place in Namibia, South Africa, Swaziland, Tanzania, Zambia and Zimbabwe, with South Africa containing the highest proportion of irrigated area. Of these countries that irrigate maize, the maize produced in South Africa and Namibia has the highest blue water content. The majority of maize production in SADC is attributable to green water. Even in South Africa and Namibia, the blue water content is low in comparison to green water content.

\subsection{Net water savings at the SADC level}

\subsubsection{Total virtual water}

When the total virtual water content of the maize produced in all SADC countries is taken into account, maize trade within the $S A D C$ region results in a net virtual water saving for the region of $3126 \times 10^{6} \mathrm{~m}^{3}$ (Table 4 ). The largest proportion of these savings is achieved as a result of South Africa exporting maize to other SADC countries, with the export of maize to 
Table 2. Average water requirements and rainfall (total and effective) for maize production in each of the SADC countries.

\begin{tabular}{lcccc}
\hline Country & $\begin{array}{c}\text { Crop Water } \\
\text { Requirements }\end{array}$ & Rainfall & $\begin{array}{c}\text { Effective } \\
\text { Rainfall }\end{array}$ & $\begin{array}{c}\text { Irrigation } \\
\text { Requirements }\end{array}$ \\
\hline Angola & 448 & 740 & 403 & 46 \\
Botswana & 638 & 312 & 265 & 373 \\
DRC & 414 & 843 & 397 & 17 \\
Lesotho & 548 & 422 & 246 & 302 \\
Madagascar & 545 & 683 & 351 & 194 \\
Malawi & 475 & 881 & 427 & 48 \\
Mauritius & 494 & 961 & 449 & 45 \\
Mozambique & 544 & 786 & 447 & 97 \\
Namibia & 620 & 276 & 114 & 506 \\
South Africa & 591 & 426 & 231 & 360 \\
Swaziland & 551 & 664 & 377 & 174 \\
Tanzania & 476 & 564 & 297 & 178 \\
Zambia & 451 & 900 & 428 & 23 \\
Zimbabwe & 553 & 548 & 298 & 254 \\
\hline
\end{tabular}

Table 3. Yields, irrigated area and virtual water content (blue, green and total) of maize produced in each of the SADC countries.

\begin{tabular}{|c|c|c|c|c|c|c|}
\hline \multirow[b]{2}{*}{ Country } & \multirow[b]{2}{*}{$\begin{array}{l}\text { Crop Yield } \\
\left(\mathrm{tha}^{-1}\right)\end{array}$} & \multirow{2}{*}{$\begin{array}{c}\text { Area } \\
\text { Irrigated } \\
(\%)\end{array}$} & \multicolumn{3}{|c|}{ Virtual Water Content } & \multirow{2}{*}{$\begin{array}{c}\text { Water } \\
\text { Availability } \\
\mathrm{m}^{3} \text { per capita }\end{array}$} \\
\hline & & & Blue & $\begin{array}{l}\text { Green } \\
\left(\mathrm{m}^{3} \mathrm{t}^{-1}\right)\end{array}$ & Total & \\
\hline Angola & 0.8 & 0 & 0 & 5329 & 5329 & 8775 \\
\hline Botswana & 0.2 & 0 & 0 & 12402 & 12402 & 1369 \\
\hline DRC & 0.8 & 0 & 0 & 5090 & 5090 & 14712 \\
\hline Lesotho & 0 & 0 & 0 & 3692 & 3692 & 2930 \\
\hline Madagascar & 1.6 & 0 & 0 & 2157 & 2157 & 17186 \\
\hline Malawi & 1.3 & 0 & 0 & 3337 & 3337 & 1200 \\
\hline Mauritius & 6.6 & 0 & 0 & 748 & 748 & 2171 \\
\hline Mozambique & 1.0 & 0 & 0 & 4652 & 4652 & 4887 \\
\hline Namibia & 1.2 & 5.1 & 211 & 927 & 1137 & 2973 \\
\hline South Africa & 2.7 & 8.7 & 117 & 868 & 986 & 939 \\
\hline Swaziland & 1.0 & 0.8 & 14 & 3688 & 3701 & 2576 \\
\hline Tanzania & 1.5 & 2.1 & 25 & 2022 & 2047 & 2115 \\
\hline Zambia & 1.5 & 0.3 & 0 & 2761 & 2761 & 6652 \\
\hline Zimbabwe & 0.7 & 1.2 & 46 & 4451 & 4497 & 932 \\
\hline
\end{tabular}

1 WRI (2008).

Botswana and Zimbabwe resulting in the largest net water savings. The largest virtual water expenditure occurs as a result of the importation of maize by South Africa. Given South Africa's low virtual water content in comparison to other SADC countries, imports into South Africa result in a net water loss, though this is insignificant in comparison to the water savings generated by the import of maize into other countries.

\subsubsection{Blue virtual water}

In contrast to the trade of total virtual water, an analysis of the quantity of blue water associated with maize that is traded between SADC countries shows a net expenditure of $66 \times 10^{6} \mathrm{~m}^{3}$ (Table 5). This is largely as a result of countries importing maize from South Africa, resulting in a net expenditure of $65 \times 10^{6} \mathrm{~m}^{3}$ for this country. Net virtual blue water expenditure occurs as a result of the export of maize from countries that irrigate (e.g. South Africa) to countries that do 
Table 4. Trade matrix illustrating net virtual water savings (positive numbers) and expenditure (negative figures) associated with the import and export of maize between SADC countries (all values in millions of cubic metres of water).

\begin{tabular}{|c|c|c|c|c|c|c|c|c|c|c|c|c|c|c|c|c|}
\hline & & \multicolumn{15}{|c|}{ IMPORTING COUNTRY } \\
\hline & & Angola & Botswana & Congo & Lesotho & Madagascar & Malawi & Mauritius & Mozambique & Namibia & South Africa & Swaziland & Tanzania & Zambia & Zimbabwe & NET \\
\hline \multirow{15}{*}{ 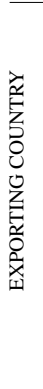 } & Angola & - & - & - & - & - & - & - & - & - & - & - & - & - & - & - \\
\hline & Botswana & -0.81 & _- & _- & _- & _- & -0.04 & -0.01 & -0.16 & -0.02 & -7.71 & -0.01 & - & -0.49 & - & -9.3 \\
\hline & Congo & - & - & - & - & - & - & - & - & - & -0.25 & - & -0.14 & -0.01 & - & -0.40 \\
\hline & Lesotho & - & - & - & - & - & _- & - & _- & _- & - & _- & - & - & _- & - \\
\hline & Madagascar & - & - & - & - & - & - & - & - & - & - & - & - & - & - & - \\
\hline & Malawi & - & 0.28 & - & - & - & - & - & 0.02 & - & -1.13 & - & -4.89 & -0.09 & 22.04 & 16 \\
\hline & Mauritius & - & - & - & - & - & - & - & - & - & - & - & - & - & - & - \\
\hline & Mozambique & - & - & _- & _- & _- & -9.38 & _- & _- & _- & -0.26 & - & -7.73 & -16.28 & _- & -34 \\
\hline & Namibia & 4.32 & 0.66 & - & - & - & - & - & - & - & -1.18 & - & - & - & - & 3.8 \\
\hline & South Africa & 107.63 & 688.29 & 14.06 & - & 7.11 & 17.45 & -0.001 & 291.19 & 6.38 & - & - & 24.55 & 169.72 & 1659.76 & 2986 \\
\hline & Swaziland & - & - & - & - & - & -0.23 & - & - & - & - & - & - & - & - & -0.23 \\
\hline & Tanzania & _- & - & 6.17 & _- & _- & 20.00 & _- & 2.65 & _- & -0.44 & _- & _- & 61.26 & 40.45 & 130 \\
\hline & Zambia & 1.43 & 9.46 & 3.49 & 0.14 & - & 4.37 & - & - & - & -5.93 & 0.33 & -0.11 & - & 23.36 & 37 \\
\hline & Zimbabwe & - & - & - & - & - & -0.03 & -0.01 & - & - & -1.86 & - & -0.002 & -1.43 & - & -3.3 \\
\hline & NET & 112.58 & 698.69 & 23.72 & 0.14 & 7.11 & 32.14 & -0.02 & 293.70 & 6.36 & -18.76 & 0.32 & 11.68 & 212.67 & 1745.61 & \\
\hline
\end{tabular}

Table 5. Trade matrix illustrating net virtual blue water savings (positive numbers) and expenditure (negative figures) associated with the import and export of maize between SADC countries (all values in millions of cubic metres of water).

\begin{tabular}{|c|c|c|c|c|c|c|c|c|c|c|c|c|c|c|c|c|}
\hline & & \multicolumn{15}{|c|}{ IMPORTING COUNTRY } \\
\hline & & Angola & Botswana & Congo & Lesotho & Madagascar & Malawi & Mauritius & Mozambique & Namibia & South Africa & Swaziland & Tanzania & Zambia & Zimbabwe & NET \\
\hline \multirow{15}{*}{ 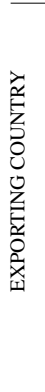 } & Angola & - & - & - & - & - & - & - & - & - & - & - & - & - & - & - \\
\hline & Botswana & _- & _- & _- & _- & _- & _- & _- & _- & _- & 0.08 & _- & _ & _- & _- & 0.08 \\
\hline & Congo & _- & _- & _- & _- & _- & _- & _- & _- & _- & 0.007 & _- & 0.001 & _- & _- & 0.01 \\
\hline & Lesotho & - & - & - & - & - & - & - & - & - & - & - & - & - & - & - \\
\hline & Madagascar & - & - & - & - & - & - & - & - & - & - & - & - & - & - & - \\
\hline & Malawi & - & - & - & - & - & - & - & - & - & 0.06 & - & 0.10 & - & 0.87 & 1.02 \\
\hline & Mauritius & - & - & - & - & - & - & - & - & - & - & - & - & - & - & - \\
\hline & Mozambique & - & - & - & - & - & - & - & - & - & 0.008 & - & 0.08 & 0.003 & - & 0.09 \\
\hline & Namibia & -0.22 & -0.01 & - & - & - & - & - & - & - & -0.72 & - & - & - & - & -0.96 \\
\hline & South Africa & -2.9 & -7.08 & -0.40 & - & -0.71 & -0.87 & - & -9.33 & 3.92 & - & - & -2.13 & -11.20 & -34.00 & -65 \\
\hline & Swaziland & - & - & - & - & - & -0.01 & - & - & - & - & - & - & - & - & -0.01 \\
\hline & Tanzania & - & - & -0.05 & - & - & -0.39 & - & -0.03 & - & 0.04 & - & - & -2.13 & -0.34 & -2.23 \\
\hline & Zambia & - & - & - & - & - & -0.003 & - & - & - & 0.39 & 0.005 & 0.004 & - & 0.61 & 1.00 \\
\hline & Zimbabwe & - & - & - & - & - & -0.001 & - & - & - & 0.04 & - & - & -0.04 & - & - \\
\hline & NET & -3.13 & -7.10 & -0.45 & - & -0.71 & -1.28 & - & -9.36 & 3.92 & -0.11 & 0.005 & -1.96 & -13.36 & -32.19 & - \\
\hline
\end{tabular}

not irrigate maize. Savings occur as a result of countries with high blue water content importing maize from countries with a lower blue water content (e.g. Namibia importing maize from South Africa). Net savings are also achieved by those countries that do not irrigate maize (e.g. Mozambique) exporting maize to countries that do irrigate.

\subsection{South African maize production analysis}

While maize is produced in all of South Africa's WMAs, the majority is produced in the Upper, Middle and Lower Vaal WMAs (Fig. 2); together, these WMAs account for almost $70 \%$ of the total national maize production. Other relatively important maize production areas include the Olifants (12\%) and Upper Orange (6\%) WMAs. In total, almost $90 \%$ of South Africa's maize is produced within these five WMAs. Irrigation of maize takes place in all of South Africa's WMAs, with the Gouritz, Fish and Tsitsikamma, Limpopo, Lower Orange and Luvuvhu and Letaba WMAs having particularly large proportions of area under irrigation (over 40\%) (Fig. 3). The lowest percentage of irrigated maize occurs in the Inkomati and Upper, Middle and Lower Vaal WMAs (less than 10\%). At a national level, approximately $91 \%$ of South Africa's maize is produced under dryland conditions, while $9 \%$ is irrigated.

The total virtual water content of maize varies widely amongst the different WMAs, from as high as $1000 \mathrm{~m}^{3} \mathrm{t}^{-1}$ in the Limpopo WMA to less than $400 \mathrm{~m}^{3} \mathrm{t}^{-1}$ in the Usuthu and Mhlatuze WMA (Fig. 4). At a national scale, the virtual water content of maize is $733 \mathrm{~m}^{3} \mathrm{t}^{-1}$, with the virtual water content of maize produced in the Upper, Middle and Lower Vaal (major production areas) approximately equal to the national average. More importantly, due to the low irrigation of maize in these WMAs, the blue water content of maize is relatively low, indicating an efficient use of water (i.e. high yields and production with relatively low irrigation input per tonne of crop produced). In contrast, the Fish to Tsitsikamma, Limpopo, Lower Orange and Olifants Doring WMAs all have very high ratios of blue to green water content. This results in a relatively high total blue water use in 


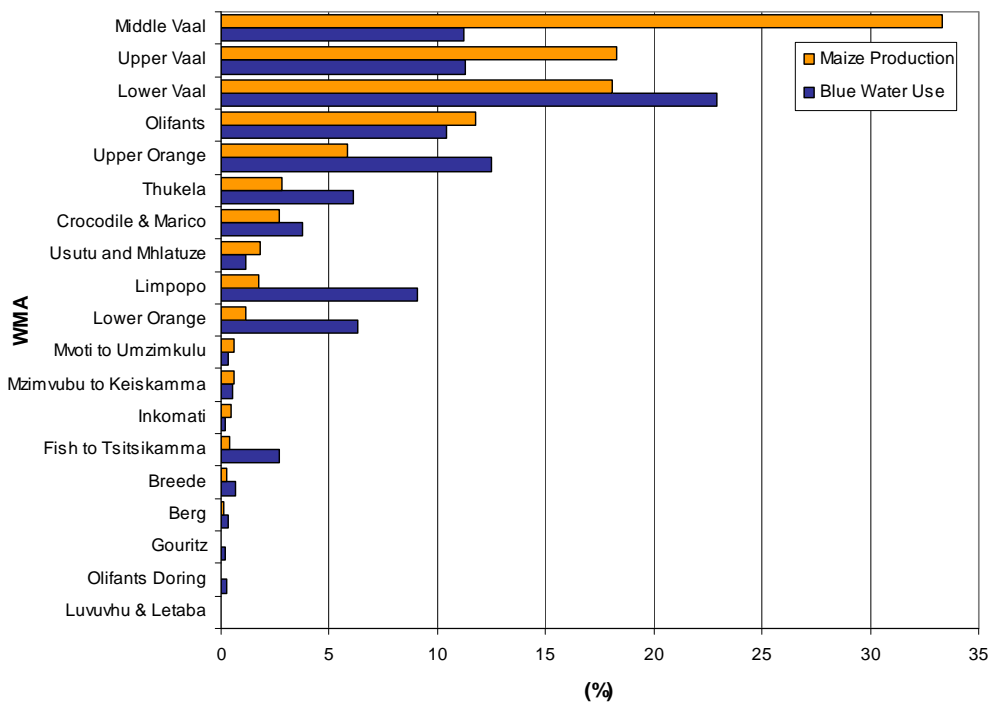

Fig. 2. Percentage of production and blue water use per Water Management Area (WMA) for national maize production in South Africa.

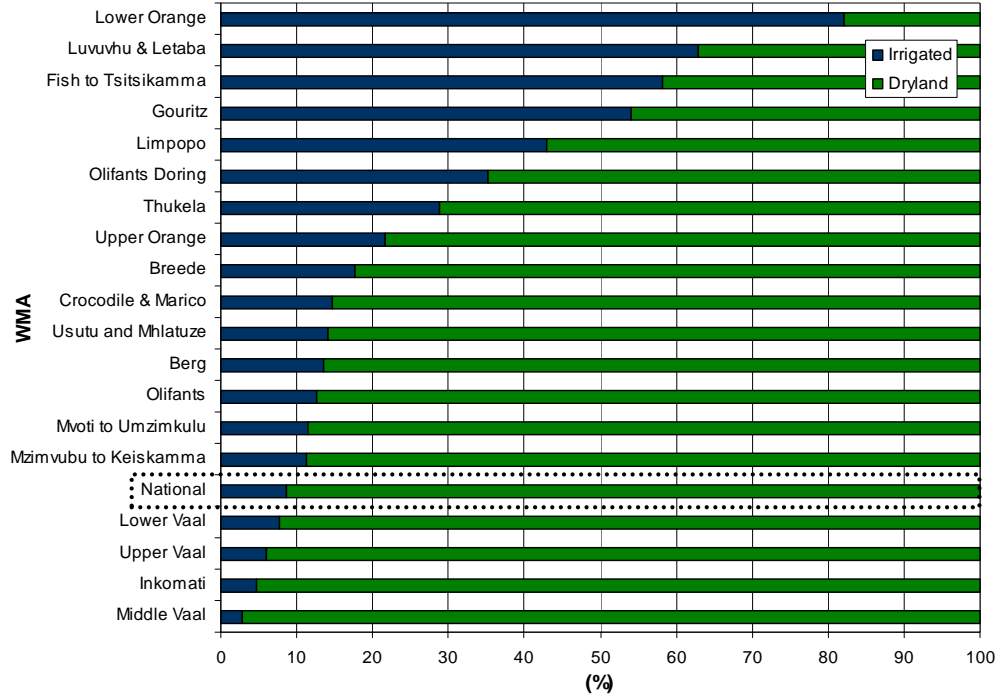

Fig. 3. Percentage of maize grown under irrigation (blue bars) and dryland (green bars) for all of South Africa's WMAs and summarized for the whole country (National; in dotted box).

comparison to total production (Fig. 2). The Limpopo and Lower and Upper Orange WMAs in particular use high percentages of the total national blue water use in relation to their percentage of national maize production, representing a relatively inefficient use of water. In total these WMAs result in only $9 \%$ of the national production, yet use $31 \%$ of the total blue water used in maize irrigation. In contrast, the Vaal WMAs are responsible for $70 \%$ of the national production, using $45 \%$ of the total blue water used for maize irrigation.

\section{Discussion}

\subsection{SADC maize trade}

Maize is clearly the most important crop with regards to virtual water trade in South Africa and the entire SADC region. Studies have shown that South Africa has increasingly exported high value crops and imported low value (high mass crops) (Earle, 2001). It is important to note that this analysis comprised only one calendar year. Annual variations in rainfall and other climatic conditions will result in variable yields, which in turn will result in varying virtual water content values from year to year (Oki and Kanae, 2004). 


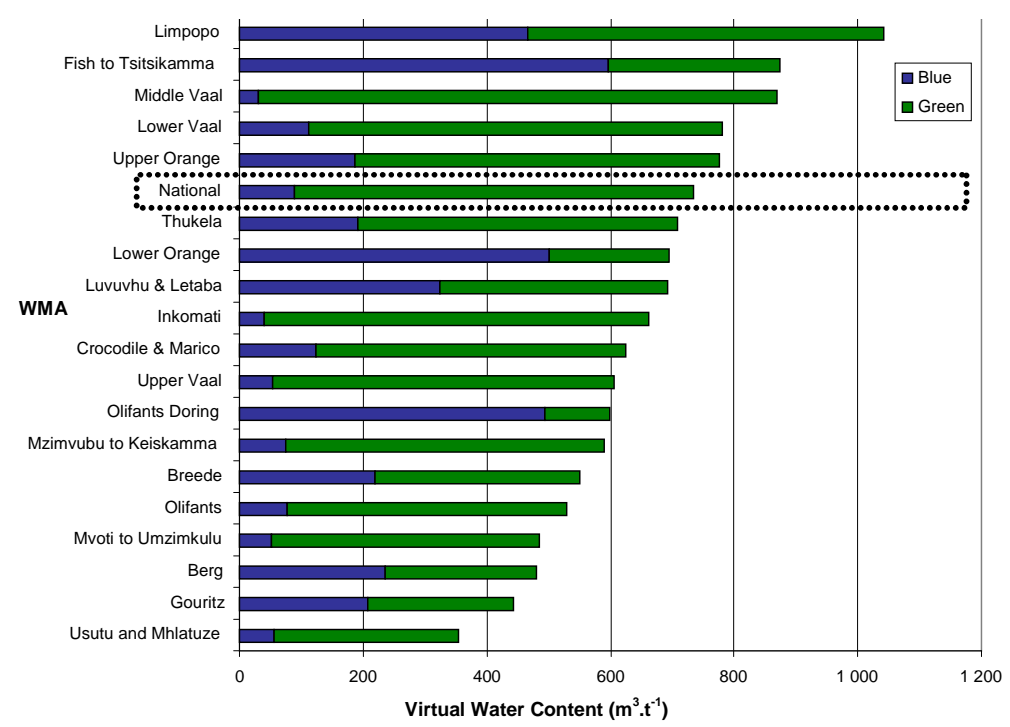

Fig. 4. Virtual water content of maize produced in all of South Africa's WMAs, and at the national scale (in dotted box). Blue bars represent blue water content (derived from irrigation) and green bars represent green water content (derived from rainfall).

The example of maize, however, illustrates how virtual water trading can be used to highlight the water implications of trade policies, revealing inefficient use or loss of water, and emphasizing the need for a detailed assessment of water use efficiency across the entire agricultural sector. The majority of maize grown in the SADC region is traded within the region, with South Africa being the largest producer and exporter (Table 1). Most of the South African-grown maize is destined for use in other SADC countries that produce maize with a comparatively higher virtual water content (Table 1 and Table 3). Even though crop water requirements for maize are lower in most other SADC countries than in South Africa, the maize productivity in these countries is low (Table 2), resulting in a comparatively high total virtual water content (Table 3). An improvement in agronomic practices and associated yields would result in a lower virtual water content for maize in these countries. Current trade patterns therefore result in a total net saving of water $\left(3126 \times 10^{6} \mathrm{~m}^{3}\right)$ as a large proportion of maize is exported from countries with a low virtual water content (predominantly South Africa and to a lesser extent Tanzania) to countries where the virtual water content of maize is higher (Tables 3 and 5). In particular, trade from South Africa to Zimbabwe, where the virtual water content of maize is amongst the highest in the SADC region, results in large savings of virtual water (Table 4). The largest virtual water expenditure occurs as a result of South Africa importing maize from SADC countries where the virtual water content for maize is comparatively higher.

The concept of virtual water trading is essentially an analysis of the trade of agricultural products based on their water content, with the emphasis on encouraging water saving in countries that are water scarce (Hoekstra and Hung, 2005). In the SADC context, South Africa, Botswana, Malawi and
Zimbabwe are highly water scarce, with water availability less than $1500 \mathrm{~m}^{3}$ per capita per year (Table 3 ). Therefore, from a virtual water trading perspective, these countries would benefit through importing, rather than exporting, "water-rich" crops, allowing the internal water savings to be used for more beneficial uses (e.g. production of higher value crops, economic development, industry etc.). Currently, based on the quantity of maize traded in the region, South Africa is clearly not a beneficiary of such a strategy. South Africa and Zimbabwe both experience chronic water stress with an annual per capita water availability below $1000 \mathrm{~m}^{3}$ (Table 3). Maize trade is therefore highly beneficial to Zimbabwe as this country experiences greatest water savings through its current trade policy. In contrast, South Africa experiences the greatest water expenditure, in spite of the fact that is one of the most water scarce countries in the region. Care is therefore needed when interpreting the values for net, total water savings as presented in this study. The net water savings achieved in the SADC region are primarily as a result of South African maize production being more water efficient than the major importing countries. Even though South Africa produces more "crop per drop" than major importers, most importing countries have more abundant water resources and can therefore potentially afford to use more water for maize production. Water savings therefore do not occur where they are needed most and current trade and virtual water savings in the SADC region are driven by crop productivity rather than water scarcity.

Presently, less than a quarter of the global cereal trade occurs from water-rich to water-scarce countries (de Fraiture et al., 2004). Many other factors determine trade decisions, such as crop productivity (as illustrated in this study), food security, loss of employment (in the case of reducing 
agricultural output) and the reluctance of states to be dependent on importing food from other countries (Wichelns, 2001; Qadir et al., 2003). South Africa is an important producer and exporter of maize in the region and the implementation of a virtual water strategy aimed at saving water and the resulting reduction in maize productivity would likely place the food security of neighbouring nations at risk. From a regional perspective, a strategy to increase the productivity of maize production in major importing countries (many of which are suited to maize production based on abundant blue water resources and high effective rainfalls) and a shift towards greater South African dependence on maize imports, could also result in a net saving of water resources in the SADC region, particularly in countries where it is needed most (i.e. South Africa, Botswana and Zimbabwe).

Real water savings occur when irrigation (or blue water) water is saved as a result of trade. The green water component (i.e. water for crop growth derived from rainfall) cannot be saved as it is difficult for it to be allocated to other (nonagricultural) essential uses (Guan and Hubacek, 2006). In fact, the use of green water for agricultural production represents a highly beneficial and sustainable use in comparison to blue water (Aldaya et al., 2008). Water used for irrigation has many possible alternative uses (i.e. domestic use, industry, mining etc.) and therefore represents a high opportunity cost (Yang et al., 2006). Analysis of blue water trade via agricultural products therefore provides a more realistic indication of real water savings (de Fraiture et al., 2004). This feature is becoming more prominent in virtual water studies and many workers have sought to partition the relative contribution of green and blue water to virtual water savings (e.g. Chapagain et al., 2006; Yang et al., 2006; Schreier et al., 2007). Our study supports the views expressed by these authors and shows that trade analysis using total virtual water content (i.e. the sum of green and blue water content for a crop) can provide a misleading picture of the actual water savings that have been achieved. The analysis of the trade in blue water flows (Table 5) contradicts the findings of an evaluation of total virtual water flows (Table 4) and shows that current trade policies within the SADC region actually result in a net water expenditure. Although the total virtual water content of maize produced in South Africa is amongst the lowest in the SADC region, the blue water content is amongst the highest (Table 3), resulting in comparatively large volumes of blue water leaving the country. Furthermore, many of the countries to which South Africa exports maize do not irrigate maize at all. Therefore blue water savings are not achieved by the importing country because that country would not have used blue water resources to produce the crop. Results of this study therefore highlight the importance of partitioning the virtual water content of a crop into green and blue water when analysing water savings associated with international crop trade. The estimated national virtual water content for maize $\left(986 \mathrm{~m}^{3} \mathrm{t}^{-1}\right)$ is considerably lower than the $1609 \mathrm{~m}^{3} \mathrm{t}^{-1}$ calculated by Chapagrain and Hoekstra (2004). Values presented in the latter study were calculated based on climatic conditions derived from capital cities of the countries included in the analysis. The study presented here shows that a more comprehensive analysis can potentially result in significantly different values and care should be taken to make decisions based on using virtual water content values that have not been derived at a fine level of detail.

\subsection{Impact of maize production at WMA scale}

Given the limitations of implementing a national virtual water trading strategy and the reliance of other SADC countries on exports from South Africa, it is difficult to envisage a national reduction in maize output aimed at alleviating water scarcity. However, considering that only $8 \%$ of South Africa's total maize production is exported to SADC, a strategy aimed at decreasing production in WMAs that are both highly water stressed and produce maize inefficiently, together with a slight increase in imports to account for the shortfall could be an option to alleviate localised water scarcity at a sub-national scale, whilst ensuring food security both in South Africa and the rest of SADC. In this respect calculating the virtual water content of crops at the WMA scale provides useful information on the water use efficiency of crop production. This in turn can identify those areas that would benefit from a virtual water trading strategy.

The majority of research relating to virtual water trade in agricultural crops has taken place at an international scale and have focussed on the import and export of crops between countries and the virtual water flows associated with such trade strategies. Studies have increasingly emphasized the need to link virtual water with national and regional water resource management (Yang and Zehnder, 2007). For example, in countries experiencing heterogeneous climatic conditions, virtual water can potentially be traded nationally or locally (Horlemann and Neubert, 2007). A number of studies have investigated the application of virtual water trading at a smaller provincial or catchment scale, within a country (i.e. between provinces or catchment basins within a country) (Guan and Hubacek, 2006; Ma et al., 2006). Schreier et al. (2007) analysed the virtual water content of different crops within catchments as an indicator of the relative efficiency of water use for those crops. Given the low average and heterogeneous nature of rainfall in South Africa, an analysis of the virtual water content of crops at the WMA scale may provide valuable inputs into decision making with regards to sustainable allocation of limited resources.

This argument is supported when national irrigation statistics and virtual water content of maize is compared to that of the individual WMAs. At the national scale the total virtual water content is relatively low $\left(733 \mathrm{~m}^{3} \mathrm{t}^{-1}\right)$. This value is even lower than that calculated for the SADC maize trade analysis and again illustrates the difference in values achieved as a result of data used. This value is likely to be the 
most accurate considering the level of detail that went into the calculations. Whilst the blue water content is amongst the highest in the SADC region, this is still a relatively small component of the total virtual water content, with the majority being comprised of green water (Table 3 ). The total virtual water content (as well as green and blue water contributions) varied greatly amongst the WMAs as would be expected by the varying climatic conditions and yields (Fig. 4). The Upper, Middle and Lower Vaal WMAs are the most important production areas, producing maize with a relatively high total virtual water content, but more importantly, with a low ratio of blue to green water content (Fig. 4). High production results in high total blue water use, however, a comparison of the percentage contribution to the national maize production versus the percentage of national blue water use for irrigation of maize in these WMAs indicates a relatively efficient use of blue water (Fig. 2). Nationally therefore, maize production in South Africa would appear to be relatively water efficient.

However, for some WMAs, in comparison to the national estimate, maize has a high blue water content, is irrigated extensively and may therefore be impacting significantly on available water resources at this localised scale. The percentage of total blue water use for maize irrigation in the Limpopo, Lower and Upper Orange WMAs is higher than would be expected, based on maize production in these WMAs (Fig. 2). In the case of the Limpopo and Lower Orange WMAs, this is as a result of the high blue water content of the maize that is produced and, given the relatively low production (1.7 and $1.1 \%$ of the total national maize production, respectively), represents an inefficient use of blue water resources. The Limpopo and Lower Orange WMAs are both over allocated by approximately 23 and $8 \times 10^{6} \mathrm{~m}^{3}$, respectively (DWAF, 2004). Based on results from this study, current blue water use for irrigation of maize in these WMAs is 337 and $674 \%$ (for the Limpopo and Lower Orange, respectively) higher than the quantity by which the WMAs are over allocated. In addition, the blue water content of maize produced in the Fish to Tsitsikamma and Olifants Doring WMAs is also high, yet accounts for a small proportion of the total (national) maize production. With the exception of the Fish to Tsitiskamma, these WMAs are highly stressed (DWAF, 2004) and maize production is clearly inefficient and contributes little to national production while using large quantities of a scarce water resource. An overall water saving could result via a shift to the production of more water efficient crops in these WMAs, with the shortfall in maize being produced by expanded maize production in other more water efficient WMAs (i.e. the Vaal WMAs) that rely predominantly on rainfall, or through increased imports.

This study therefore emphasises the need for analysing the virtual water content of crops at different scales so as to ensure that water is allocated as efficiently as possible within South Africa, especially given its current high agricultural production. Given the heterogeneous distribution of rainfall and water resources across the country, the calculation of the virtual water content of a crop at smaller spatial scales can provide valuable information as to crop water use efficiency in relation to water availability. Horlemann and Neubert (2007) suggest that IWRM should be a priority in tackling water scarcity and virtual water trading used as a complementary strategy. In this respect, virtual water content values represent a useful means to determine the water use of crops in different areas of the country and allow decision makers or managers to effect changes in the production of crops at the WMA scale, with the emphasis on increasing water use efficiency and alleviating water scarcity.

\section{Conclusions}

Blue water contributes directly to water scarcity whilst use of green water in agriculture is a relatively beneficial use of water. Analysis of virtual water associated with crop trade should therefore focus on blue water so as to determine actual water savings within the context of prevailing water scarcity. Furthermore while a national estimate of the virtual water content of a crop may indicate a relatively efficient use of water (i.e. maize production in South Africa), an analysis of the virtual water content at smaller scales (i.e. WMAs in South Africa) can reveal inefficient use of water for the same crop (i.e. high blue water use in relation to productivity). At these smaller, localised scales, the implementation of a virtual water trading policy may potentially significantly contribute to alleviating water scarcity. Therefore, analysis of the virtual water content of crops and trading of agricultural products at different scales (i.e. regional, national and WMA) is an important consideration within the context of alleviating water scarcity and encouraging improved water use efficiency.

Acknowledgements. This research was made possible through Parliamentary Grant funding received from the CSIR, Natural Resources and the Environment, Project No. JNWS024.

Edited by: N. Romano

\section{References}

Aldaya, M. M., Hoekstra, A. Y., and Allan, J. A.: Strategic importance of green water in international trade. Value of Water Research Report Series No. 25, UNESCO-IHE, Delft, The Netherlands, 2008.

Chapagain, A. K. and Hoekstra, A. Y.: Water Footprints of Nations. Volume 2: Appendices. Value of Water Research Report Series No. 16, UNESCO-IHE, Delft, The Netherlands, 2004.

Chapagain, A. K., Hoekstra, A. Y., and Savenije, H. H. G.: Water saving through international trade of agricultural products, Hydrol. Earth Syst. Sci., 10, 455-468, 2006,

http://www.hydrol-earth-syst-sci.net/10/455/2006/.

Crosby C. T. and Crosby C. P.: SAPWAT: A computer programme for establishing irrigation requirements and scheduling strategies 
in South Africa. WRC Report No: 624/1/99. Water Research Commission, Pretoria, South Africa, 1999.

de Fraiture, C., Cai, X., Amarasinghe, U., Rosegrant, M. and Molden, D.: Does International Cereal Trade Save Water? The impact of virtual water trade on global water use, Colombo, Comprehensive Assessment Secretariat, 2004.

DoA: Abstract of Agricultural Statistics, Department of Agriculture, online available at: www.nda.agric.za, 2007.

DWAF: National Water Resource Strategy. First Edition. Pretoria, Department of Water Affairs and Forestry, 2004.

Earle, A.: The role of virtual water in food security in southern Africa. Occasional Paper No. 33. School of Oriental and African Studies, University of London, 2001

Falkenmark, M.: The massive water scarcity now threatening Africa - why isn't it being addressed?, Ambrio, 18(2), 112-118, 1989.

FAO (Food and Agriculture Organization of the United Nations): CROPWAT Model, Food and Agricultural Organization, Rome, Italy, 2003.

FAO (Food and Agriculture Organization of the United Nations): Irrigation in Africa in figures: AQUASTAT survey - 2005. Food and Agricultural Organization of the United Nations, Rome, Italy, 2005.

FAO (Food and Agriculture Organization of the United Nations): FAOSTAT. Food and Agriculture Organisation of the United Nations, online available at: http://faostat.fao.org/site/291/default. aspx, last access: December 2007.

Guan, D. and Hubacek, K.: Assessment of regional trade and virtual water flows in China, Ecol. Econ., 61(1), 159-170, 2006.

Hartkamp, A. D., White, J. W., Rodriguez Aguilar, A., Bänziger, M., Srinivasan, G., Granados, G., and Crossa, J.: Maize production environments revisited: a GIS-based approach, Mexico, DF, CIMMYT, 2000.

Hoekstra, A. Y. and Hung, P. Q.: Globalisation of water resources: international water flows in relation to crop trade, Glob. Environ. Change, 15, 45-56, 2005.

Horlemann, L. and Neubert, S.: Virtual Water Trade: A realistic concept for resolving the water crisis?, Bonn, German Development Institute, 2007.
Ma, J., Hoekstra, A. Y., Wang, H., Chapagain, A. K., and Wang, D.: Virtual versus real transfers within China, Philos. T. Roy. Soc. B, 361, 835-842, 2006.

Maasdorp, G.: Regional trade and food security in SADC, Food Policy, 23(6), 505-518, 1998.

Oki, T. and Kanae, S.: Virtual water trade and world water resources, Water Sci. Technol., 49(7), 203-209, 2004.

Qadir, M., Boers, T. M., Schubert, S., Ghafoor, A., and Murtaza, G.: Agricultural water management in water-starved countries: challenges and opportunities, Agr. Water Manage., 62, 165-185, 2003.

Schreier, H., Lavkulich, L., and Brown, S.: Real and virtual water and water footprints: A comparison between the Lower Fraser Valley and the Okanagan Basin. Vancouver, Institute for Resources, Environment and Sustainability, The University of British Columbia, 1-32, 2007.

STATSSA (Statistics South Africa): Census of Agriculture Provincial Statistics 2002. Financial and Production Statistics. Statistics South Africa. Report No. 11-02-08, 2002.

Wichelns, D.: The role of "virtual water" in efforts to achieve food security and other national goals, with an example from Egypt, Agr. Water Manage., 49, 131-151, 2001.

WRI (World Resources Institute): Earth Trends: Environmental Information, online available at: http://earthtrends.wri.org, last access: December 2008.

WWC (World Water Council): E-Conference Synthesis: Virtual Water Trade - Conscious Choices, 2004.

Yang, H. and Zehnder, A. J. B.: "Virtual water": an unfolding concept in integrated water resources management, Water Resour. Res., 43, W12301, doi:10.1029/2007WR006048, 2007.

Yang, H., Wang, L., Abbaspour, K. C., and Zehnder, A. J. B.: Virtual water trade: an assessment of water use efficiency in the international food trade, Hydrol. Earth Syst. Sci., 10, 443-454, 2006, http://www.hydrol-earth-syst-sci.net/10/443/2006/. 